\title{
MOTIVASI ORANG TUA TEHADAP KELANJUTAN PEDIDIKAN ANAK SAMPAI DI PERGURUAN TINGGI PADA MASYARAKAT DESA SAJANG KECAMATAN SEMBALUN KABUPATEN LOMBOK TIMUR
}

\author{
Andi Mulyan \\ Dosen Prodi Sosiologi, Universitas Nahdlatul Ulama ntb
}

\begin{abstract}
Abstrak; Penelitian ini berangkat dari problematika tentang rendahanya tingkatan pendidikan pada masyarakat Desa Sajang Kec. Sembalun Kab. Lombok Timur.Hal ini membuat ketertarikan pada peneliti untuk mengkaji lebih dalam tentang motivasi orang tua terhadap kelajutan pendidikan anak ke jenjang tiggi, sehigga diangkat judul "Motivasi Orang Tua Terhadap Kelajutan Pendidikan Anak Sampai Di Perguruan Tinggi Pada Masyarakat Desa Sajang Kecamatan Sembalun Kabupaten Lombok Timur". Dalam penelitian ini ditemukan bahwa motivasi orang tua terhadap kelanjutan pendidikan anak ke jenjang yang lebih tinggi tergolng tinggi, hanya saja terkendala oleh kondisi ekonoi yang melemah sehigga rata-rata generasi muda yang ada di desa tersebut memiliki tingkatan pendidikan yang rendah, dan jarang yang mamu melanjutkan ke erguruan tinggi. Penelitian ini menggunakan teori motivasi adalah suatu dorongan kepada seseorang yang terjadi secara inernal dan internal.Pendekatan yang digunakan adalah pendekatan kualitatif, sementara jenis penilitian ini adalah penelitian dasar atau murni yang bertujuan untunk menemukan pengetahuan baru yang sebelumnya belum pernah.Teknik pengumpulan data dilakukan dengan metode wawancara, observasi, dan dokumentasi.Untuk analis data digunakan metode deskriptif kualitatif.
\end{abstract}

Kata Kunci: Motivasi Orang Tua, Kelanjutan Pedidikan Anak Sampai Di Perguruan Tinggi

\section{PENDAHULUAN}

Dalam dunia pendidikan motivasi orang tua sangat dibutuhkan tehadap pendidikan anak agar anak tetap bereran aktifdaam menjalankantugasnya sebagai peserta didik hingga mencapai suatu kesuksessan. Dalam dunia pendidikan motivasi sangat dibututuhkan untuk menjadi peyemangat anak, motivasi atau dorongan orang tua kepada anak yang sedang menjalani proses pendidikan menjadi sumber kekuatan agara terus bersemangat dalam belajar.

Desa sajang Kecamtan Sembalun KabupatenLombok Timur memliki kondisi pendidikan yang masih tergolong rendah.Hal ini dapat dilihat dari jumlah sarjana yang ada di desa ini masih kurang, sehingga rendahnya kuantitas pendidikan berimbas pada indeks pembangunan manusia di wilayah ini secara khusus dan pada umumnya.

Berangangkat dari permasalahan pendidika yang terjadi di Desa Sajang Kecamatan Sembalun Kabupaten Lombok Timur, penulismengkaji tentang faktor penyebab munculnya permasalahan pendidikan tersabut. Dari observasi yang dilakukan tentang fenomena pendidikan di Desa Sajang, penulis tertarik untuk Jurnal Ilmiah Mandala Education melakukan penelitian di desa tersebut dengan judul"Motivasi Orang Tua Terhadap Kelanjutan Pendidikan Anak Sampai Perguruan Tinggi Di Desa Sajang Kecamatan .Sembalun Kabupaten.Lombok Timur Fokus Perrmasalahan

Berdasarkan latar belakang masalah, maka yang menjadi fokus permasalahan dalam penelitian ini adalah Motivasi Orang Tua Terhadap Kelanjutan Pendidikan Anak sampai Perguruan Tinggi Di Desa Sajang Kecamatan Sembalun Kabupaten Lombok Timur.

Rumusan Masalah

1. Bagaimana motivasi orang tua dalam melanjutkan pendidikan anaknya keperguruan tinggi pada desa sajang Kecamatan Sembalun Kabupaten Lombok timur

2. Sejauh mana keberhasilan orang tua dalam memotivasi anak terhadap kelanjutan pendidikan diperguruan tinggi pada Desa Sajang Kecamatan Sembalun Kabupaten Lombok Timur.

Tujuan Penelitian

1. Untuk pengetahui motivasi orang tua terhadap kelanjutan pendidikan anak di perguruan tinggi pada Desa Sajang 
Kecamatan Sembalun Kabupaten Lombok Timur

2. Untuk mengetahui sejauh mana keberhasilan orang tua terhadap kelanjutan pendidikan anak di perguruan tinggi pada Desa Sajang Kecamatan Sembalun Kabupaten Lombok Timur.

a. Manfaat Penelitian

Penelitian ini diharapkan bermanfaat bagi kita semua baik secara teoritis maupun praktis

1. Manfaat Teoritis

a. Agar hasil penelitian ini memberikan informasi dan gambaran tentang motivasi orang tua terhadap kelanjutan pendidikan anak diperguruan tinggi

b. Agar pembaca dapat menambah wawasan dan pengetahuan tentang motivasi orang tua terhadap kelanjutan pendidikan anak di perguruan tinggi.

2. Manfaat Praktis

a. Agar para orang tua dapat memberikan motivasi pendidikan pada anak sesuai dengan tingkatan umur

b. Hasil penelitian ini diharapkan bermanfaat bagi masyarakat dan pemerintah, khususnya pada masyarakat Sajang Kecamatan Sembalun Kabupaten Lombok Timur.

\section{LANDASAN TEORI \\ Pengertian Motivasi.}

Motivasi merupakan salah satu hal yang sangat penting bagi setiap individu. Dengan adanya motivasi, seseorang dapat bangkit dari keputus-asaan,karena motivasi juga merupakan suatu hal yang bisa membangkitan seseorang dari keoptimisanya, baik dalam masalah pribadi maupun masalah dengan orang lain secara umum. Motivasi itu sendiri dapat diperoleh seseorang baik secara internal maupun secara eksternal.

Sujono Trimo memberikan pengertian motivasi yaitu suatu kekuatan penggerak dalam perilaku individu, baik yang akan menentukan arah maupun daya tahan. Menurut Chiffrod T.Morgan bahwa motivasi bertalian dengan tiga hal yang sekaligus merupakan aspek-aspek dari pada motivasi.Ketiga hal tersebut adalah keadaan yang mendorong tingkah laku yaitu tingkah laku yang didorong oleh keadaan tersebut, motiving behaviordan tujuan dari tingkah laku tersebut (goal or endsof such behavior).

Jurnal Ilmiah Mandala Education

\section{METODE PENELITIAN \\ Desain Penelitian}

Desain penelitian menanyakan sebuah sikap yang berkepentingan, dan mempunyai gambaran yang jelas tentang bagaimana keterkaitan antara variabel yang ada pada tugas penelitian dan apa yang hendak dilakukan oleh seseorang peneliti dalam mengumpulkan data.

1. Jenis Pendekatan

Dalam penelitian ini digunakan pendekatan kualitatif.Penelitian kualitatif adalah penelitian yang dilakukan dalam situasi yang wajar dan data yang dikumpulkan umumnya bersifat kualitatif.Pendekatan kualitatif lebih berdasar pada filsafat fenomenologis yang mengutamakan penghayatan. Metode kualitatif berusaha memahami dan menafsirkan makna suatu peristiwa interaksi tingkah laku manusia dalam situasi tertentu menurut prespektif peneliti sendiri ( Husnaini Usman, 2004 : 81) dengan bahasa yang sederhana.Zuriah (2007:91) mengatakan bahwa pendekatan kualitatif adalah pendekatan penelitian yang lebih banyak menggunakan logica-hipotetikoverifikatif.

\section{Jenis Penelitian}

Jenis penelitian yang digunakan dalam penelitian ini adalah penelitian dasar atau murni.Jujun S.Suriasumantri (1985) menyatakan bawa penelitian dasar atau murni yaitu penelitian yang bertujuan untunk menemukan pengetahuan baru yang sebelumnya belum pernah diketahui (Sugiono 2007:4).Penelitian dasar untuk mngembangkan teori dan tidak memperhatikan kegunaan yang langsung bersifat praktis.

\section{Lokasi Penelitian}

Penelitian ini dilakukan di Desa Sajang Kecamatan Sembalun Kabupaten Lombok Timur Nusa Tenggara Barat. Peneliti memilih lokasi penelitian tersebut karena banyaknya ditemukan anak yang kurang mendapatnkan motivasi entah dari diri sendiri maupun dari orang tua untuk melanjutkan pendidikanya kejenjang yang lebih tingi.

\section{Subyek Penelitian}

Peneliti dalam penelitian ini merupakan instrument kunci yang memiliki peran yang sangat utama dalam keseluruhan proses 
penelitian karena setelah memperoleh data, peniliti tidak langsumg menyajikan data dalam laporan, melainkan peneliti harus mengkonfirmasikan dahulu dengan sumber informan untuk mendapat data yang benar dan akurat. Adapun sumber data dalam penelitian ini adalah subyek dimana data ini diperoleh (Arikunto,2002:106).Subyek dalam penelitian ini adalah bagaimana motivasi dari orang tua kepada anaknya baik yang sedang menempuh pendidikan maupun yang putus sekolah.

\section{Jenis dan Sumber Data}

a. Data primer, yaitu data yang diperoleh melalui obsrvasi dan wawancara langsung ditempat kejadian dan tanya jawab terhadap warga setempat tentang motivasi orang tua terhadap pendidikan anak.

b. Data sekunder adalah data yang diperoleh melalui dokumentasi, yang merupakan datasekunder adalah data yang diperoleh dari kantor desa ataupun dari instansi lain yang terkait dengan objek yang akan diteliti yakni bagaimana motivasi orang tua terhadap pendidikan anak.

Tehnik Pengumpulan Data

\section{Data Primer}

Data primer adalah data yang diperoleh dan dikumpulkan secara langsung dari sumber-sumber asli, dalam hal ini pemerintah desa dan seluruh masyarakat yang dapat memberikan data yang dibutuhkan peneliti yang sesuai masalah dalam penelitian. Cara pengumpulan sebagai berikut.

a. Wawancara

Wawancara adalah mencari informasi tentang suatu hal dengan mengajukan pertanyaan (narasumber) secara detail. Wawancara digunakan sebagai tekhnik pengumpulan data apabila peneliti ingin mendapatkan dan mengetahui hal-hal dari informan secara lebih mendalam dan jumlah informan sedikit.

b. Observasi

Observasi adalah suatu proses yang kompleks, yaitu suatu proses yang tersusun dari berbagai proses biologis dan psikologis. Dua diantaranya yang terpenting adalah proses-proses dan ingatan. Dari segi proses pelaksanaan pengumpulan data, observasi dapat dibedakan menjadi dua yaitu observasi dan non partisipasi observasi, selanjutnya dari Jurnal Ilmiah Mandala Education segi instrumentasi yang digunakan maka observasi dibedakan menjadi observasi terstruktur dan tidak struktur.

Nasution (2003:106) menjelaskan bahwa observasi adalah kegiatan yang dilakukan untuk memperoleh informasi tentang kelakuan manusia seperti terjadi dalam kenyataan.Jadi dapat disimpulkan bahwa metode observasi diartikan sebagai pengamatan dan pencatatan secara sistematis terhadap gejala yang nampak pada objek penelitian.

c. Dokumentasi

Menurut Moleong (:161) bahwa dokumentasi adalah setiap pertanyaan tertulis yang disusun oleh seseorang atau lembaga untuk keperluan pengujian peristiwa atau akunting. Jadi dapat disimpulkan bahawa metode dokumentasi adalah suatu tehnik pengumpulan data yang digunakan sebagai acuan dalam mencari dan referensi yang berkenaan langsung dengan masalah dalam penelitian. Adapun yang dijadikan data penunjang dalam penelitian ini adalah berupa buku-buku, catatan atau jenis dokumentasi tertulis lainya, seperti profil desa, foto-foto, dan catatan atau agenda yang dibuat oleh tokoh yang ada di desa.

2. Data Sekunder

Data sekunder adalah data yang dikumpulkan oleh lembaga-lembaga yagn terkait dan dipublikasikan berupa bacaan atau literatur yang berkaitan dengan penelitian ini.Pengumpulan data sekunder salah satunya studi perpustakaan.

Uji keapsahan data

Untuk menetapkan keabsahan data diperlukan tehnik pemeriksaan.Menurut Moleong (2002:173) ada empat kriteria yang digunakan untuk memeriksa keabsahan data, yaitu derajat kepercayaan, keteralihan, kebergantungan, dan kepastian.Berdasarkan penjelasan tersebut maka dalam penelitian ini penelitis menggunakan tehnik keabsahan data yang sesuai dengan kriteria yang telah disebutkan diatas dimana peneliti memperhatikan tingkat kepercayaan data, kepastian data, ketergantungan antara data yang satu dengan data yang lainya, dan kepastian data yang telah terkumpul.

Dalam penelitian ini, data yang dikumpulkan adalah data-data yang bersifat 
alamiah dimana data-data yang terkumpul lebih banyak didapatkan dari informan yang kadang-kadang memiliki keterbatasan karena disebabkan oleh keletihan atau keterbatasan mengingat dapat menyebabkan kekeliruan, sehingga peneliti perlu memperhatikan keteralihan dan kebergantungan yang juga sering disebut dengan validitas dan reliabilitas data. Selain itu perlu juga diperhatikan kepastian objektivitas (sumber) dimana dalam hal ini peneliti melakukan seleksi terhadap data-data yang telah diberikan oleh narasumber dan tidak tergantung kepada pandangan atau persetujuan seseorang serta berusaha mencari keterangan dari narasumber yang jujur, faktual, dan dapat dipastikan keteranganya.

Setelah data terkumpul dan sudah diuji keabsahannya maka data-data tersebut perlu diorganisasikan, diseleksi, dan kemudian disusun dalam bentuk tulisan.Meskipun datanya cukup variatif namun dengan dilakukanya dengan pengecekan keabsahan data dengan kriteria-kriteria yang telah ditetapkan sebelumnya maka data yang diperoleh betul vailid dan akurat. Dalam penelitian ini data-data yang telah diperoleh dilapangan nanti akan dibanding-bandingkan kemudian dianalisis untuk menarik generalisasi atau kesimpulan.

Tehnik Analisis Data

Analisis data dalam penelitian merupakan sesuatu kegiatan yang sangat penting dan memerlukan ketelitian serta kekritisan dari penulis.

Dari pengertian diatas, maka untuk mnganalisis hasil penelitian dalam laporan ini menggunakan analisis induktif.Pendekatan induktif adalah suatu analisis data yang memungkinkan temuan-temuan penelitian muncul dari keadaan umum, tema-tema dominan dan signifikan yang ada dalam data tanpa menagabaikan hal-hal yang muncul oleh struktur bioligisnya.Jadi metode ini sangat tepat bila digunakan untuk menganalisis data yang dimulai dengan gejala-gejala yang sifatnya umum kemudian diuraiakan menjadi kesimpulan yang sifatnya khusus.

\section{HASIL PENELITIAN PEMBAHASAN}

\section{A. Deskripsi Lokasi}

\section{Sejarah Desa Sajang}

Desa Sajang merupakan salah satu desa yang ada di Kecamatan Sembalun Kabupaten Lombok Timur.Nama Desa Sajang diambil dari kata sajian/sesajen dimana pada jaman dahulu sebelum orde baru.Sajang merupakan pintu gerbang utama menuju danau segara anak dan gunung rinjani, dan di Sajang- lah terdapat mangku gunung yang bergelar mangku angin dan mangku tersebut adalah orang yang menghuni sajang pertama kalinya yakni bernama "TITIK KASTURA".

Konon pada waktu itu, setiap orang yang hendak kedanau segara anak dan gunung rinjani terlebih dahulu memohon restu kepada sang mangku yang ada di Sajang dengan mnyerahkan sajian/sesajen sebagai isyarat memohon keselamatan dari gangguan gaib penghuni gunung renjani.

Desa Sajang berdiri pada tahun 1962 yang meliputi empat kekeliangan, namun seiring dengan perkembangan pembangunan dan untuk meningkatkan pelayanan masyarakat, maka terbitlah Peraturan Daerah Kabupaten Tingkat II Lombok Timur Nomor : 7 tahun 1981 tentang istilah kekeliangan dirubah menjadi kekadusan yang dikepalai oleh kepala dusun, akhirnya pada tahun 1983 empat kekeliangan tersebut dimekarkan menjadi 7 kekadusan yakni :

1. Kadus Bawak Nao Daya

2. Kadus Bawak Nao laut

3. Kadus Lelongken

4. Kadus Sajang

5. Dusun Birak

6. Dusun Dasan Bilok

7. Dusun Landaian

Kemudian Desa Sajang mengalami perubahan kembali tepatnya pada tanggal 31 maret 2003 dan dimekarkan menjadi 2 desa yakni Desa sajang dan Desa Sajang Utara yang sekarang bernama Desa Bilok Petung.

2. Keadaan Umum Desa

a. Letak desa

Desa Sajang terletak di wilayah bagian utara Kecamatan Sembalun dengan batas-batas wilayah sebagai berikut:

$>$ Sebelah utara berbatasan dengan Desa Bilok Petung 
$>$ Sebelah timur berbatasan dengan Desa Obel-Obel

> Sebelah selatan berbatasan dengan Sembalun Lawang

$>$ Sebelah barat berbatasan dengan Kabupaten Lombok Barat

b. Iklim

Curah hujan 1.826-2000 Mm/tahun dan hujan turun pada bulan januari, februari, maret dan yang paling sedikit pada bulan april dan mei. Selain itu seterusnya mengalami musim kering, suhu rata-rata 29-35 oC tinggi tempat : 850 dari pemukiman laut .

3. Keadaan Penduduk

Jumlah penduduk Desa Sajang sampai bulan maret 2009 berjumlah 3.249 jiwa, terdiri dari laki-laki yaitu 1.561 jiwa, perempuan 1.688 jiwa tergabung dalam 915 kepala keluaraga (KK).

a. Keadaan Penduduk Tingkat Pendidikan

1. Jumlah penduduk buta huruf yaitu 310 orang

2. Jumlah penduduk tidak tamat SD yaitu 351 orang

3. Jumlah penduduk tamat SD yaitu 1.563 orang

4. Jumlah penduduk tamat SLTP yaitu 805 orang

5. Jumlah penduduk SLTA yaitu 195 orang

6. Jumlah penduduk tamat D1 yaitu 3 orang

7. Jumlah penduduk tamat D2 yaitu 17 orang

8. Jumlah penduduk tamat D3 yaitu 6 orang

9. Jumlah penduduk tamat S1 yaitu 12 orang

b. Keadaan Penduduk Menurut Agama dan

Kepercayaan:

$>$ Islam yaitu 3.014 orang

Hindu yaitu 235 orang

c. Keadaan Penduduk Menurut Kepadatan dan Perkembangannya

$>$ Luas wilayah desa sajang yaitu 18.980

Jumlah penduduk seluruhnya 3.249

4. Prasanarana Sosial

1. Prasarana sosial di bidang pendidikan yaitu TK,SD,SMP,SMA

2. Prasarana sosial dibidang keagamaan yaitu masjid, musholah, majelis ta'lim, TPQ dan Pure

Jurnal Ilmiah Mandala Education
3. Prasarana sosial di bidang perumahan yaitu rumah permanen, rumah semi permanen, rumah sederhana, dan rumah darurat

4. Prasarana sosial di bidang kesehatan yaitu sumur gali, mata air, PAM, MCK, Jamban Keluarga, Bak sampah dll..

\section{PEMBAHASAN}

1. Kondisi Pendidikan

Pendidikan merupakan kunci menuju kemajuan suatu peradaban, baik tidaknya generasi masa depan ditentukan oleh kualitas pendidikanya saat ini. Jika kita coba bandingan diantara setiap peradaban bangsabangsa di dunia, bangsa paling maju peradabannya adalah bangsa yang paling mapan sistem pendidikanya.

Terkait dengan hal di atas, khususnya di Negara kita Indonesia masih ditemukannya beberapa kelompok masyarakat yang sistem atau tingkat pendidikannya masih tergolong rendah.Salah satu contoh desa yang masih memprihatinkan tinkat pendidikannya adalah Desa Sajang yang ada di Kecamatan Sembalun Kabupaten Lombok Timur.

Berdasarkan pemantauan, rendahnya tingkatan pendidikan di Desa Sajag adalahi disebabkan oleh kesadaran masyarakat tentang pentingnya pendidikanya rata-rata masih rendah.Rata-rata generasi muda yang ada di desa ini lebih memilih untuk bekerja dari pada menempuh pendidikan, dengan suatu alasan bahwa dengan bekerja lebih cepat menghasilkan uang dari pada sekolah yang lebih banyak mengeluarkan biaya.Hal ini tentu berkaitan dengan peran orang tua dalam memberi motivasi kepada anak supaya lebih mengenyam pendidikan yang lebih tinggi.

Rendahanya tingkatan pendidikan di Desa Sajang juga disebabkan oleh jarak tempuh lokasi sekolah dengan tempa tiggal.Berdasar dari hasil wawancara, rata-rata generasi muda yang mengalami masalah pendidikan mengutarakan bahwa salah satu kurangnya pendidikan di desa ini adalah lokasi sekolah yang lumayan jauh. Mereka pun juga mengeluhkan tentang alat transportasi yang kurang memadai, sedangkan penghasilan orang tua belum tentu seimbang untuk membelikan alat transpotasi kepada anaknya 
yang akan dipergunakan untuk bolak-bolak ke sekolah.

Mulyani,, seorang warga desa sajang yang masih duduk di kelas tiga SMA menyadari bahwa iya tak bisa melanjutkan pendidikan ke jenjang lebih tinggi karena salah satu faktor penyebanya adalah kondisi ekonomi keluarga yang sangat memprihatinkan. Meski iya sendiri mengakui bahwa kuliah itu sangat penting namun melihat keadaan ayahnya yang hanya sebagai pengembala hewan sehingga membuat dirinya terhambat dalam melanjutkan kependidikannya yang lebih tinggi. Dalam kondisi eknomi keluarga yang demikian, semangat generasi muda untuk melanjutkan pendidikan kejenjang lebih tinggi tentu menjadi terhambat.

2. Motivasi Orang Tua Untuk Melanjutnkan Pendidikan Anaknya Ke Perguruan Tinggi Motivasi adalah suatu kekuatan penggerak untuk membentuk perilaku individu yang baik dalam menjalani kehidupan.Dalam pendidikan, motivasi juga sangat di butuhkan untuk membangkitkan semangat pada generasi muda.Namun suatu permasalahan yaitu tat kala motivasi anak atau orang tua terhadap pendidikan anak sangat rendah tentu sulit menstabilkan pengembangan pembangunan bagi generasi penerus bangsa.

Pada masyarakat Sajang yang ada di Kecamatan Sembalun Kabupaten Lombok Timur, motivasi orang tua terhadap pendidikan anak, telebih dalam kelanjutan pendidikan anak ke jenjang yang lebih tinggi tergolong tinggi. Hal ini sesuai dengan ungkapan ibu khotimah (52th) bahwa agar anaknya menjadi anak yang sukses, meski anak itu bukan anak kandungnya sendiri namun betapa besar harapan dari seorang ibu terhadap kelajutan pendidikan anak di jenjang yang lebih tiggi. Demikian juga dengan Amaq ati (50thn) juga mengungkapkan bahwa iya menyekolahkan anaknya agar tidak merasakan kehidupan yang kurang beruntung seperti apa yang ia rasakan. Namun apalah daya iya tak mampu menyekolahkan anaknya keperguruan tinggi, diakibatkan lemahnya ekonomi, namun baginya bahwa lulus dari SMA saja sudah menjadi kebanggaan baginya, mengingat iya tak pernah sekolah karena tidak ada biaya pada masanya dulu walau hanya sebatas mengenyam sekolah dasar.

Menurut Asganan (55 thn) yang juga salah seorang warga masyarakat Desa Sajangi mengungkapkan "saya menyekolahkan anak untuk bisa berbuat baik kepada keluarga karena baginya harta yang kekal hanyalah sekolah," ungkapnya yang juga menyampaikan tentang kesadarannya terhadap tantangan hdup yang dihadapi anakanak semakin berkembang. Dalam hal ini pula Asganan dalam hal pendidikan anak, ia pun menyerahkan anaknya kedalam naungan pondok pesantren.

Pengalaman tentang pahitnya menjalani hidup tanpa bekal ilmu menjadikan para orang tua menjadi sadar bahwa jika mereka tidak menyekolahkan anaknya maka anakanak itu akan kembali merasakan pahitnya kehidupan yang pernah dialami para orang tua.Hanya saja rata-rata masyarakat di Desa Sajag tekendala dalam hal biaya terhadap kelanjutan pendidikan anak, khususnya ke jenjang yang lebih tinggi.

Dari gambaran di atas dapat digarisbawahi bahwa rata-rata orang tua yang ada di Desa Sajang memliki motivasi tinggi terhadap kelanjutan pendidikan anak, khususnya ke jenjang pedidikan yang lebih tinggi, akan tetapi rata-rata terkedala oleh kondisi ekonomi keluarga yang tidak menjamin. Hal ini pula mengakibatkan banyaknya generasi muda yang mengalami pengangguran, bahkan putus sekolah.

\section{KESIMPULAN}

Motivasi orang tua di desa sajang Kec.Sembalun Kab.Lombok Timur terhadap kelanjutan pendidikan anak kenjenjang yang lebih tinggi adalah sangat tinggi. Namun permasalahan yang muncul dan menjadi kendala bagi keberlangsungan kependidikan anak adalah kodisi ekonomi. Akan tetapi, walaupun kondisi perekonomian masyarakat Desa Sajang Kecamatan Sembalun Kabupaten Lombok Timur tergolong rendah, namun semangat masyarakat tehadap pendidikan anak tidak selalu bisa dihentikan sebab masih ada jalan lain yang bisa di tempuh untuk meraih cita-cita.

\section{Saran}

Seperti yang telah di bahas sebelumnya bahwa salah satu kendala yang paling besar 
dalam dunia pendidikan adalah faktor ekonomi, olehnya itu diharapkan kepada pemerintah dapat memperhatikan ataupun menganggarkan biaya pendidikan murah bagi generasi penerus bangsa.

\section{DAPTAR PUSTAKA}

Ahmad Tanzeh, Pengantar Metode Penelitian, (Yogyakarta: Teras, 2009).

Firman Abdullah, tanggung jawab Orang Tua dalam pendidikan Anak, (Semarang: Pelita Ibu,1988)

Husaini Usman dan Purnomo Setiadi Akbar, "Metode Penelitian Sosial"( Jakarta: Bumi Aksara, 1996).

M. Idrus, Metode Penelitian Ilmu-ilmu Sosial: Pendekatan Kualitatif dan Kuantitatif, (Yogyakarta: UII Press, 2007)

Sardiman, Interaksi dan Motivasi Belajar (Jakarta: Raja Grafindo Persada, 2001)

Siti Partini Sudirman, "Psikologi Pendidikan", (Bandung: PT. Remaja Rasda Karya, 1990).

Slameto. Belajar dan faktor-faktor yang mempengaruhi, Jakarta : Rineka Cipta 1995

Sudirman ,"Bimbingan orang tua dan anak , (yogyakarta: Percetakan Studing 1984. Sumadi suryabrata, " beberapa prinsip psikologi pendidikan”, ( Yogyakarta :fakultas psikologi UGM). 